\title{
Chrzest Polski w oczach historyka języka
}

\section{The Baptism of Poland from the perspective of historical linguistics}

\author{
Bogdan Walczak \\ Wydział Humanistyczny, Akademia im. Jakuba z Paradyża w Gorzowie Wielkopolskim, \\ ul. Teatralna 25, 66-400 Gorzów Wielkopolski, Polska; \\ Wydział Filologii Polskiej i Klasycznej, Uniwersytet im. Adama Mickiewicza w Poznaniu, \\ ul. Fredry 10, 61-701 Poznań, Polska; \\ e-mail: bwalczak@amu.edu.pl
}

\begin{abstract}
Abstrakt
W zwięzłym szkicu autor zwraca uwagę na następujące konsekwencje chrztu Polski: wzmocnienie państwa (jako głównego czynnika sprawczego powstania języka polskiego), przyjęcie pisma w postaci alfabetu łacińskiego, przyjęcie łaciny w funkcji pierwszego (chronologicznie) języka literackiego i uniwersalnego języka kultury chrześcijańskiej w jej wariancie rzymskim, przyjęcie europejskich wzorców oświatowych, rozstrzygającą rolę Kościoła w ukształtowaniu podstaw polskiego języka literackiego oraz ogólne usytuowanie Polski w kręgu kultury Zachodu.
\end{abstract}

Słowa kluczowe: chrzest Polski; pisownia polska; powstanie języka literackiego; wpływy czeskie i łacińskie.

\begin{abstract}
The author of this brief article draws attention to the following consequences of the baptism of Poland: empowering of the country (as a main causative factor of the emergence of the Polish language), the adoption of the Latin alphabet for the writing system, establishing Latin as the first literary language (chronologically) and as the universal language of the Christian culture in its Roman variant, adopting European educational patterns, the crucial role of the Church in creating the foundation for the Polish literary language and the general situation of Poland in the Western cultural heritage.
\end{abstract}

Keywords: baptism of Poland; Polish writing system; the emergence of the literary language; Czech and Latin influences.

Chrzest przyjęty przez Mieszka I w roku 996 rozpoczął długotrwały (kilkuwiekowy) proces chrystianizacji Polski i był faktem o ogromnym znaczeniu dla losów naszego narodu. W niniejszym szkicu skoncentrujemy się, zgodnie z kompetencjami autora, który jest językoznawcą - historykiem języka, na skutkach tego wydarzenia dla dziejów języka polskiego. Przedstawimy je tutaj w telegraficznym skrócie, w kilku punktach. 
Po pierwsze, organizacja kościelna umocniła państwo, a państwo było głównym czynnikiem sprawczym powstania języka polskiego. Należy to rozumieć tak, że granice państwowe, notabene w przeważającej mierze naturalne, umożliwiły wyodrębnienie się polszczyzny spośród bliskich jej dialektów zachodniosłowiańskich: granice te z jednej strony zakreślały obszar rozpowszechniania się zrodzonych wewnątrz nich polskich zmian językowych, a z drugiej - nie dopuszczały na terytorium nimi objęte przeobrażeń dokonujących się na zewnątrz. O rozumie politycznym pierwszych Piastów, Mieszka I i Bolesława Chrobrego, najlepiej świadczą ich skuteczne działania zmierzające do uniknięcia jakiejkolwiek obcej zależności na płaszczyźnie kościelnej. Już dwa lata po chrzcie, w 968 roku, zostało utworzone polskie biskupstwo (w kontekście naszego tematu nie jest istotny jego status, tzn. pytanie, czy było to biskupstwo misyjne) z siedzibą w Poznaniu, a w roku 1000 powstała metropolia (arcybiskupstwo) z siedzibą w Gnieźnie, której podlegały nowo założone biskupstwa w Krakowie, Wrocławiu i Kołobrzegu. Wkrótce w skład metropolii gnieźnieńskiej weszło też już wcześniej powołane biskupstwo z siedzibą w Poznaniu. Dla porównania warto w tym miejscu przypomnieć, że Czesi, którzy przyjęli chrześcijaństwo znacznie wcześniej od nas, własnej metropolii ze stolicą w Pradze doczekali się dopiero w XIV wieku [w sprzyjających okolicznościach za Karola IV, który jak wiadomo, był równocześnie królem Czech i cesarzem Cesarstwa Rzymskiego (od XV wieku Narodu Niemieckiego)]. Wykształcone dość szybko zręby niezależnej polskiej prowincji kościelnej stanowiły niezwykle istotny czynnik scalający państwo i naród, jeśli bowiem powstanie scentralizowanego organizmu państwowego stworzyło nową wspólnotę ziem i plemion, które weszły w jego skład, to organizacja kościelna, z arcybiskupem gnieźnieńskim na czele, związała tę wspólnotę dodatkowymi, a jak się w przyszłości miało okazać, bardzo silnymi więzami. Na zewnątrz przyjęcie chrześcijaństwa umocniło międzynarodową pozycję młodego państwa polskiego w gronie niemal wyłącznie już podówczas chrześcijańskich państw Europy. Szczególnie poprawiła się pozycja Polski wobec Cesarstwa, którego wschodnie marchie ekspansję niemczyzny na wschód osłaniały zazwyczaj pozorami szerzenia chrześcijaństwa wśród pogańskich Słowian. Po chrzcie Mieszka I w stosunku do państwa Piastów ten pretekst upadł.

Po drugie, ogromnej wagi skutkiem chrztu Polski w dziedzinie historycznojęzykowej było przyjęcie pisma, którego przed chrztem nasi przodkowie nie znali. Swego czasu wysuwano wprawdzie hipotezę o istnieniu przed chrystianizacją słowiańskiego pisma runicznego, podobnego charakterem do run germańskich czy celtyckich, i w XIX wieku, stuleciu słynnych falsyfikatów (by się ograniczyć do przykładów rzekomo staroczeskich poematów Václava Hanki), doszło nawet do sfałszowania dowodów na poparcie tej tezy - by przywołać pokryte znakami, które miały być rzekomymi słowiańskimi runami, tzw. kamienie mikorzyńskie. Okazały się one jednak, jak wiadomo slawistom, jedynie zręcznym falsyfikatem i tym samym hipoteza run słowiańskich, jako nie znajdująca żadnego naukowego potwierdzenia, ostatecznie upadła. Dziś nie ulega więc już najmniejszej wątpli- 
wości, że pismo przyszło do nas wraz z chrztem Polski. Nie sposób przecenić znaczenia tego faktu. Jak obecność języka uważa się za symbol rozgraniczenia świata zwierzęcego i ludzkiego (homo sapiens i homo loquens to zatem synonimy), tak posiadanie pisma stanowi granicę między społeczeństwem pierwotnym a cywilizowanym. Pismo umożliwia utrwalanie osiągniętej wiedzy o świecie oraz społecznych doświadczeń. Jest ono zarazem koniecznym warunkiem powstania i rozwoju piśmiennictwa, w tym także pisanej literatury pięknej i twórczości naukowej - a więc podstawowych składników narodowej kultury.

Podobnie jak u innych Słowian, tak i w państwie Piastów chrystianizacja pociągnęła za sobą nie tylko przyjęcie pisma, lecz także jego określony kształt formalny. Chrzest w obrządku łacińskim (z Rzymu za pośrednictwem Czech) zdecydował bowiem o przyjęciu alfabetu łacińskiego. Alfabet ten nie był jednak, co oczywiste, przystosowany do potrzeb i wymogów języka polskiego (przede wszystkim miał za mało znaków - zasób głoskowy łaciny, zwłaszcza w obszarze konsonantyzmu, był bez porównania mniejszy od zasobu głoskowego polszczyzny). A że w średniowieczu nie było i być nie mogło żadnego ośrodka koordynacyjnego w tym względzie, z przystosowaniem alfabetu łacińskiego do języka polskiego wszyscy piszący po polsku, całe skryptoria i kancelarie (co najwyżej najważniejsze ośrodki piśmiennicze mogły wytwarzać pewne lokalne tradycje) musiały sobie radzić na własną rękę. W tej sytuacji adaptacja alfabetu łacińskiego do wymogów fonetycznych języka polskiego trwała kilka wieków i można uznać, że proces ten zakończył się dopiero na gruncie pierwszych polskich druków, tzn. w latach dwudziestych XVI wieku (zresztą nie bez świadomego działania drukarzy). Przy okazji warto jednak w tym miejscu sprostować pewien dość często jeszcze dziś powtarzany, a ewidentnie błędny pogląd - o wyższości w tym względzie alfabetu greckiego, który bez większych kłopotów został zaadaptowany do fonetyki słowiańskiej w postaci cyrylicy. Otóż należy z naciskiem stwierdzić, że alfabet grecki (co byłoby bardzo łatwo wykazać, lecz chyba nie ma takiej potrzeby) nie był wcale lepiej niż łaciński predysponowany do adaptacji do fonetyki słowiańskiej. Co ważniejsze, należy z jeszcze większym naciskiem podkreślić, że cyrylica bynajmniej nie była wynikiem przystosowania alfabetu greckiego do wymogów języka słowiańskiego. Była natomiast skutkiem prostej transpozycji (litera w literę - dziś taką konwersję pisma nazywamy transliteracją) pierwszego, starszego pisma słowiańskiego - głagolicy, stworzonej specjalnie dla języka staro-cerkiewno-słowiańskiego przez św. Konstantyna (Cyryla), który się okazał kongenialnym filologiem i zaprojektował dla tego języka alfabet wprost idealny. Cyrylica zaś powstała jako wynik zastąpienia (w Bułgarii, dokąd się schroniła większość uczniów św. Metodego po wygnaniu z Moraw, a gdzie miejscowa elita intelektualna znała język grecki) liter głagolskich przestylizowanymi literami greckimi (lub, rzadziej, uproszczonymi głagolskimi - w tych wypadkach, gdy alfabet grecki nie dysponował stosownymi znakami). W świetle przypomnianych wyżej bezspornych faktów nie ulega wątpliwości, że mówienie o cyrylicy jako wyniku adaptacji alfabetu greckiego do wymogów fonetyki słowiańskiej polega 
na nieporozumieniu. Nie zmienia to oczywiście faktu, że Słowianie, którzy przyjęli chrześcijaństwo z Rzymu, a wśród nich i nasi przodkowie, musieli, jak już stwierdziliśmy, przez wieki dostosowywać alfabet łaciński do fonetyki swoich języków (w tym kręgu kulturowym wielki filolog, w osobie Jana Husa, objawił się stosunkowo późno, a do tego oddziaływanie jego idei i pomysłów pisowniowych zahamowała jego śmierć na stosie w czasie soboru w Konstancji; oczywiście Hus nie został spalony za reformę ortografii czeskiej, ale dla ludzi średniowiecza każdy pomysł heretyka musiał być z góry podejrzany). Był to jednak wysiłek opłacalny - dzisiaj łacinka jest najszerzej rozpowszechnionym alfabetem świata i najniewątpliwiej najbardziej ekspansywnym: na łacinkę przechodzą narody posługujące się wcześniej innym alfabetem (jak Turcy, którzy w 1928 roku na fali rewolucji młodotureckiej przyjęli alfabet łaciński w miejsce od wieków stosowanego pisma arabskiego), alfabetu łacińskiego używają najpopularniejsze języki sztuczne w rodzaju esperanta, wprowadza się go też do zapisywania języków, które wcześniej w ogóle nie znały pisma. Inaczej rzecz się miała tylko w byłym Związku Radzieckim, gdzie rosyjską grażdanką (świeckim wariantem cyrylicy) zastąpiono nie tylko dawniej używane rodzaje pisma, na przykład alfabet arabski w języku azerskim, baszkirskim, kirgiskim, turkmeńskim itd., arabski, a potem łaciński w języku kazaskim (kazachskim, jak niektórzy mówią i piszą, co jest wszelako rażącym rusycyzmem), mongolski w języku buriackim, lecz także alfabet łaciński, zastosowany już po rewolucji do języków tych narodów, które przedtem w ogóle nie znały pisma (na przykład w językach tunguskich - od 1931 roku alfabet łaciński, od 1936 grażdanka, w niektórych językach ugrofińskich, na przykład mansyjskim - od roku 1932 alfabet łaciński, od 1939-1940 grażdanka, chantyjskim - od roku 1930 alfabet łaciński, od 1939-1940 grażdanka). Posługiwanie się najszerzej rozpowszechnionym alfabetem świata pociąga za sobą rozliczne awantaże (na przykład ucząc się języka obcego, na ogół nie mamy do czynienia z różnicą alfabetu, która stwarza dodatkowe trudności - starsze i średnie pokolenie Polaków, które przechodziło w szkołach podstawowych i średnich obligatoryjną naukę języka rosyjskiego, dobrze pamięta o trudnościach spowodowanych koniecznością opanowania innych bukw), najogólniej mówiąc - ułatwia korzystanie z ogólnoświatowego dorobku kulturalnego i współuczestnictwo w jego pomnażaniu.

Po trzecie, w wyniku chrztu Polska przyjęła nie tylko alfabet łaciński, ale i samą łacinę jako uniwersalny język kultury chrześcijańskiej w jej wariancie rzymskim. W pierwszych wiekach po chrzcie powstawały na ziemiach polskich wyłącznie teksty łacińskie (jak do dziś żywy hymn Gaude Mater Polonia Wincentego z Kielc), a i później długo jeszcze piśmiennictwo łacińskie przeważało ilościowo nad skromnym dorobkiem piśmiennictwa w języku ojczystym. Można więc powiedzieć, że Polska przyjęła łacinę w podwójnej roli: głównego (przynajmniej do połowy XVI wieku, dokładnie do roku 1543), potem już drugoplanowego języka literackiego oraz - w stosunku do rodzimej polszczyzny - języka wyższej kultury, języka wysokoprestiżowego w terminologii Tadeusza Lewasz- 
kiewicza. W tym miejscu znowu przyjdzie nam sprostować wciąż dość szeroko rozpowszechniony a błędny pogląd: pokutujący jeszcze mit o łacinie jako czynniku ograniczającym (w wersji bardziej skrajnej zgoła hamującym) rozwój języka narodowego. Jest prawdą, której chyba nie trzeba tutaj dowodzić, że polszczyzna musiała w konfrontacji z łaciną wywalczyć sobie należne jej (jako językowi ojczystemu) miejsce w życiu społecznym i kulturalnym. Trwało to długo i nie przyszło łatwo: jak doskonale wiadomo historykom języka polskiego, dopiero w czasach Odrodzenia polszczyzna złotego wieku przełamała hegemonię łaciny na gruncie literatury pięknej i publicystycznej, a także poważnie nadwerężyła tę hegemonię na gruncie piśmiennictwa naukowego, gdzie ostateczne zwycięstwo odniosła znacznie później, bo dopiero w epoce Oświecenia. Wszystko to prawda, z drugiej jednak strony trudno zaprzeczyć temu (i tylko na pozór teza ta brzmi paradoksalnie), że niezrozumiałość łaciny dla szerokich kręgów średniowiecznego społeczeństwa polskiego (nierzadko z ówczesnymi elitami politycznymi) na swój sposób stymulowała powstanie i rozwój polskiego języka literackiego. Dowodzi tego bezspornie porównanie $\mathrm{z}$ sytuacją tych narodów słowiańskich, które przyjęły chrześcijaństwo z Konstantynopola i w związku z tym język staro-cerkiewno-słowiański jako liturgiczny i literacki. Wszędzie tam narodowe języki literackie powstały bardzo późno, bez porównania później niż w Czechach czy w Polsce.

Przyczyny tego stanu rzeczy są w zasadzie oczywiste. Łacina, właśnie dlatego, że dla szerokiego ogółu wiernych była zupełnie niezrozumiała, wymagała uzupełnienia polszczyzną w funkcji języka pomocniczego - tak w liturgii (przekłady modlitw codziennych, Psatterza, Biblii, polskie kazania i pieśni), jak i w życiu społecznym (tzw. roty przysiąg sądowych, przekłady kodeksów prawnych itd.). Ta pozycja polszczyzny i te przejawy jej użycia, choć zrazu bardzo skromne, wystarczyły przecież do tego, by z upływem czasu na ich obszarze ukształtował się język literacki na drodze niwelacji różnych odrębności dzielnicowych. Tymczasem w krajach słowiańskich pozostających w kręgu kultury bizantyjskiej (Slavia Orthodoxa) rolę analogiczną do roli łaciny u nas odgrywał język staro-cerkiewno-słowiański. Był on dla szerokiego ogółu społeczeństwa tych krajów w najdawniejszej epoce całkowicie zrozumiały [jeszcze w czasach chrztu Polski zróżnicowanie językowe Słowiańszczyzny było niewielkie, a nieco wcześniej święci Konstantyn (Cyryl) i Metody, rodem z Sołunia (Salonik), bez najmniejszych kłopotów językowych prowadzili swoją misję nauczycielską na Morawach], a później, mimo rosnących różnic wywołanych rozwojem i zmianami języków słowiańskich, zrozumiały w dużej mierze - tym bardziej, że i sam się zmieniał, nabierając w poszczególnych krajach lokalnego zabarwienia (są to tzw. lokalne redakcje cerkiewszczyzny, czyli jej warianty ukształtowane w wyniku oddziaływania - zwłaszcza na poziomie fonetycznym - substratu językowego). W tej sytuacji nie mogło być mowy na przykład o przekładach tekstów liturgicznych na języki narodowe, jak to miało miejsce na obszarze Slavia Latina. Właśnie na skutek swej (zrazu całkowitej, a później względnej) zrozumiałości cerkiew- 
szczyzna mogła nie dopuścić języków narodowych do tych pomocniczych funkcji, które pełniły one w krajach o kulturze łacińskiej. I dlatego narodowe języki literackie powstały tam (tzn. w krajach liturgii słowiańskiej) bardzo późno. Pominąwszy narody południowosłowiańskie, gdzie to opóźnienie miało i dodatkowe przyczyny historyczne (niekorzystne warunki polityczne, niewola turecka itd.), porównajmy czas powstania języków literackich w Czechach, Polsce i na Rusi: w Czechach język literacki powstał w XIV wieku, w Polsce na przełomie XIV i XV stulecia (a niewykluczone, że nawet wcześniej), tymczasem w Rosji (przodującej w tym względzie na obszarze wschodniosłowiańskim) dopiero w wieku XVIII, głównie dzięki owocnym wysiłkom Michała Łomonosowa.

Po czwarte, bardzo ważnym czynnikiem rozwoju każdego języka jest jego nauczanie i kształtowanie w szkole. Trzeba więc w tym miejscu przypomnieć oczywisty fakt, że rozwój szkolnictwa w Polsce też jest skutkiem przyjęcia chrześcijaństwa. Aż do XVIII wieku szkolnictwo w zasadzie monopolizował Kościół - przejściowo, zwłaszcza w XVI wieku, wespół z innymi wyznaniami chrześcijańskimi (szkoły różnowiercze: luterańskie, kalwińskie, ariańskie itd.). Wprawdzie początkowo szkoły (klasztorne, katedralne) były wybitnie elitarne, z czasem jednak stosunkowo gęsta sieć szkół parafialnych pokryła cały kraj (historycy Kościoła zasadnie szacują, że na przełomie XV i XVI wieku na dwie parafie przypadała jedna szkoła). Oczywiście trzeba pamiętać, że w dawnych szkołach uczono głównie łaciny, jednak i tutaj nie można się było obejść bez polszczyzny w funkcji języka pomocniczego w nauczaniu. W sumie, co dziś już nie ulega najmniejszej wątpliwości, dawna szkoła odegrała w dziejach języka polskiego rolę większą niż się jej do niedawna przypisywało.

Po piąte (last but not least), wielką, może największą zasługą Kościoła (przecież najoczywistszego skutku chrztu Polski) było to, że odegrał on rozstrzygającą rolę $\mathrm{w}$ procesie ukształtowania się podstaw polskiego języka literackiego. Jego początki sięgają najprawdopodobniej przełomu XIV i XV wieku. I właśnie w pierwszym, średniowiecznym okresie jego formowania się (do końca XV stulecia) rola Kościoła jest absolutnie bezsporna i niekwestionowana. W wieku XVI, w drugim okresie kształtowania się i początkowej stabilizacji języka literackiego, najważniejsza rola w tym dziele przypadła środowisku intelektualistów skupionych wokół Akademii Krakowskiej i dworu królewskiego (kancelarii królewskiej), których opinie normatywne wprowadzały w życie krakowskie drukarnie. Choć jeszcze stosunkowo niedawno toczył się w tym względzie zawzięty spór, dziś już chyba nie ulega wątpliwości, że zgodnie z poglądami Zdzisława Stiebera i Marii Renaty Mayenowej polski język literacki ukształtował się w piśmie. Dowodzą tego częste w średniowiecznym piśmiennictwie przykłady odstępstw od kształtującej się bądź już ukształtowanej normy językowej, spowodowanych przenikaniem do tekstów rzeczywistej wymowy pisarza w chwilach dekoncentracji, osłabienia uwagi, zmęczenia itd. (na przykład tłumacz czy tylko kopista Psatterza floriańskiego uznawał za obowiązującą wymowę typu chwała, ale sam mówił fała i jeden jedyny raz, na około 150 przykładów typu chwała, owa fała mu 
się przytrafiła). Nie bez znaczenia jest też fakt (ujawniony i zinterpretowany przez Stanisława Urbańczyka), że w najbardziej literackich zabytkach (takich jak przekłady psałterzowo-biblijne, modlitewniki, literatura apokryficzna itd.) takich odstępstw od normy jest mało, natomiast obfitują w nie teksty użytkowe, których język jest zbliżony do ówczesnej polszczyzny mówionej. Przekonującym potwierdzeniem kształtowania się polskiego języka literackiego w piśmie jest sytuacja językowa z XVI, a nawet jeszcze pierwszej połowy XVII wieku (najwcześniej odtworzona przez Stanisława Urbańczyka), charakteryzująca się tym, że nawet ludzie wykształceni (poeci, pisarze, uczeni) mówili gwarą. Świadczą o tym ich autografy bądź - w wypadku poetów - analiza rymów ujawniająca rzeczywistą wymowę autora: na przykład rymy typu trwoży - obozy czy oczy - nocy, wobec obowiązującego w ówczesnej poezji kanonu rymu żeńskiego dokładnego, dowodzą, że mazurzył (gdyż wymawiał trwozy, ocy) nawet tak wielki poeta, największy staropolski epik, jak Piotr Kochanowski. Nie znamy rymowych świadectw mazurzenia Jana Kochanowskiego (mamy więc prawo sądzić, że Jan się tej nagannej a powszechnej w jego domowej ojczyźnie cechy wyzbył), jego rymy (typu niestety - wzięty czy biega - przysięga) świadczą jednak o tym, że poeta nie ustrzegł się panującej już wówczas w jego rodzinnych stronach wymowy przedniej samogłoski nosowej e jak e (tzn. że wymawiał wziety, przysiega). Taka była ówczesna rzeczywistość wymawianiowa. Dopiero w piśmie (a ściślej: w druku) dochodziło do ingerencji normy. Na jej straży stali wydawcy (redaktorzy, korektorzy i zecerzy w oficynach drukarskich), którzy nadawali tekstom obowiązującą, poprawną formę, usuwając $z$ nich cechy gwarowe. Tak więc teza o pisanej genezie polskiego języka literackiego wydaje się dzisiaj bezdyskusyjna.

Skoro zaś polski język literacki w pierwszej najważniejszej fazie rozwoju ukształtował się na gruncie średniowiecznych zabytków językowych, to znaczy, że zawdzięczamy go autorom i kopistom tych zabytków. Kim byli owi autorzy i kopiści? Z imienia znamy ich niewielu (choć wraz z postępem badań coraz więcej), nie stanowi jednak kwestii spornej fakt, że byli to niemal wyłącznie duchowni. Wiadomo, że w średniowieczu wykształcenie było w zasadzie zmonopolizowane przez duchowieństwo. Dla drugiej połowy XIV i początków XV wieku odsetek ludzi świeckich wśród ogółu wykształconych szacuje się na 6-10\%. Ponadto najważniejsze, najbardziej literackie, a więc najstaranniejsze pod względem językowym teksty średniowieczne powstawały w skryptoriach klasztornych, w środowisku wyższego duchowieństwa skupionego w kapitułach katedralnych, a później i kolegiackich, w kancelariach biskupich itd., gdzie udział pisarzy świeckich jest nie do pomyślenia. Tezę, że wśród autorów i kopistów średniowiecznych zabytków językowych wydatnie przeważali duchowni (a w najważniejszych dla procesu kształtowania się polskiego języka literackiego dziedzinach piśmiennictwa, takich jak przekłady Biblii, kazania, modlitewniki, literatura apokryficzna itp. trzeba w zasadzie przyjąć ich wyłączność), potwierdzają zresztą w całej rozciągłości wypadki znanych nam z imienia autorów i kopistów, niemal wyłącznie duchownych, zarówno mnichów, jak i księży diecezjalnych, zwykle należących 
do kręgów wyższego duchowieństwa. Ponadto częste są wypadki, gdy wprawdzie nie znamy pisarza z imienia, jednak benedyktyńska, cysterska, dominikańska, bernardyńska (bardzo często) czy augustiańska proweniencja dzieła nie ulega najmniejszej wątpliwości. Wreszcie jest rzeczą absolutnie oczywistą, że duchownymi byli autorzy i kopiści tak fundamentalnych zabytków jak Bulla gnieźnieńska, Bogurodzica, Kazania świętokrzyskie, Psałterz floriański, Rozmyślanie przemyskie. Dlatego w jednej z moich wcześniejszych prac pozwoliłem sobie na eksplicytne twierdzenie, że polski język literacki zawdzięczamy Kościołowi.

Po szóste wreszcie, w kategorii odleglejszych i bardziej pośrednich skutków w dziedzinie historycznojęzykowej aktowi chrztu można (z dobrym uzasadnieniem) przypisać to wszystko, co nasz język zawdzięcza usytuowaniu Polski w kręgu kultury Zachodu. A jest tego, jak wynika z prac Tadeusza Lewaszkiewicza, niemało. Wyliczając te elementy, choćby już tylko w trybie telegraficznego skrótu, trzeba by tu wspomnieć o oddziaływaniu języka czeskiego i łaciny, którym polszczyzna zawdzięcza podstawowy zasób najstarszych wyrazów abstrakcyjnych, służących wyrażaniu nowych treści intelektualnych i emocjonalnych, wniesionych do naszej leksyki za sprawą chrześcijaństwa i w ogóle zachodniej kultury umysłowej. Nie można zapominać, że do XVI wieku czeskie i aż do XVIII stulecia łacińskie wpływy językowe stały się bardzo poważnym współczynnikiem historii języka polskiego. Dobrze dziś wiemy, że w dziejach polszczyzny najwięcej zapożyczeń (około 10 000) dostarczyła jej łacina. Jeszcze dziś, mimo iż wiele z nich wyszło z użycia, stanowią one najliczniejszą grupę wśród wyrazów obcego pochodzenia, jak wynika z badań Małgorzaty Witaszek-Samborskiej. W wielu bardzo istotnych sferach znaczeniowych wzbogaciły one zasób wyrazowy polszczyzny i trudno sobie bez nich wyobrazić funkcjonowania naszego języka.

W niniejszym szkicu, z założenia bardzo zwięzłym (tym się tłumaczy rezygnacja z przypisów, które by musiały być bardzo rozbudowane), nie uwzględniłem wszystkich zasługujących w tym kontekście na uwagę spraw. Na przykład świadomie pominąłem wątek troski Kościoła o język polski, wyrażającej się w ustawach synodalnych gwarantujących kanonicznie zakres praw polszczyzny w Kościele i językowych kompetencji duchowieństwa. Starałem się bowiem skupić nie na faktach, lecz na zjawiskach i procesach, sproblematyzowanych, ułożonych w określone ciągi i zakresy. Do czytelnika należy ocena, w jakim stopniu mi się to udało. W moim przekonaniu nie ulega wątpliwości, że tytułowe zagadnienie, pierwszoplanowe z punktu widzenia historyka języka polskiego, mimo dziś już obszernej literatury przedmiotu wciąż pozostaje w kręgu problemów niedostatecznie opisanych.

\section{BibliogRAFIA}

Furdal A., 1977, Językoznawstwo otwarte, Opole.

Klemensiewicz Z., 1961-1972, Historia języka polskiego, cz. 1-3, Warszawa. 
Kłoczowski J., Müllerowa L., Skarbek J., 1986, Zarys dziejów Kościoła katolickiego w Polsce, Kraków.

Lewaszkiewicz T., 1992, Rola kontaktów językowych we wstępnym okresie ksztattowania się słowiańskich języków literackich (na tle ogólniejszym), w: Z polskich studiów slawistycznych, seria 8, Językoznawstwo, Warszawa, s. 117-122.

Lewaszkiewicz T., 1992, Rola przekładów Biblii w formowaniu języków literackich europejskiego kręgu kulturowego, w: Biblia a kultura Europy, red. M. Kamińska, E. Małek, t. 1, Łódź, s. 232-248.

Lewaszkiewicz T., 1994, O potrzebie nowego spojrzenia na genezę polskiego języka literackiego (z uwzględnieniem tła ogólnoeuropejskiego), w: Studia historycznojęzykowe, t. 1, red. M. Kucała, Z. Krążyńska, Kraków, s. 213-220.

Maćkowiak K., 2011, U źródet polskiej świadomości językowej (X-XV wiek), Poznań.

Mayenowa M.R., 1956, Problemy i stanowiska w dyskusji o pochodzeniu polskiego jezzya literackiego, w: Pochodzenie polskiego języka literackiego, red. K. Budzyk, Wrocław, s. $453-471$.

Moszyński L., 1984, Wstęp do filologii stowiańskiej, Warszawa.

Puchowski K., 2007, Jezuickie kolegia szlacheckie Rzeczypospolitej Obojga Narodów. Studium z dziejów edukacji elit, Gdańsk.

Rospond S., 1985, Kościół $w$ dziejach języka polskiego, Wrocław-Warszawa-KrakówGdańsk.

Słowiński L., 1978, Nauka języka polskiego w szkołach Rzeczypospolitej przedrozbiorowej, Poznań.

Stieber Z., 1956, Udziat poszczególnych dialektów w formowaniu polskiego języka literackiego, w: Z dziejów powstawania języków narodowych i literackich, red. Z. Stieber, Warszawa, s. 97-120.

Urbańczyk S., 1950, W sprawie polskiego języka literackiego. I. O dawności dialektu kulturalnego, „Język Polski” XXX, nr 3, s. 97-109.

Urbańczyk S., 1950, W sprawie polskiego języka literackiego. II. Wzrost społeczny języka literackiego, „Język Polski” XXX, nr 4, s. 145-160.

Urbańczyk S., 1953, Jaka polszczyzną mówił Jan Kochanowski i jego rówieśnicy, „Język Polski” XXXIII, nr 4, s. 214-224.

Walczak B., 1984, Chrześcijaństwo i Kościół w dziejach języka polskiego, „Życie i Myśl”, nr 4, s. 58-74.

Walczak B., 1989, Problemy językowe i pisowniowe w ZSRR. Szkic informacyjny, „Życie i Myśl", nr 7/8, s. 59-67.

Walczak B., 1991, Między Wschodem a Zachodem (Uwagi o leksyce polskiego języka literackiego), w: Dzieje Lubelszczyzny, t. 6: Między Wschodem a Zachodem, cz. 2: Piśmiennictwo pogranicza, red. R. Łużny i S. Nieznanowski, Warszawa, s. 89-103.

Walczak B., 1992, Czy tzw. dialekt kulturalny poprzedzit powstanie polskiego języka literackiego?, w: Język. Teoria - Dydaktyka, red. M. Preizner, Kielce, s. 87-97.

Walczak B., 1993, Komu zawdzięczamy polski język literacki?, w: Język a chrześcijaństwo, red. I. Bajerowa, M. Karpluk i Z. Leszczyński, Lublin, s. 23-42.

Walc zak B., 1999, Zarys dziejów języka polskiego, wydanie II, Wrocław.

Walczak B., 2004, Chronologia wpływów obcych $w$ dziejach języka polskiego w świetle nowszych prac historycznojęzykowych, w: W kręgu wiernej mowy, red. M. Wojtak, M. Rzeszutko, Lublin, s. 409-417. 
Walczak B., 2005, Rola państwa w dziejach języka polskiego, „Poznańskie Spotkania Językoznawcze”, t. XIV, red. Z. Krążyńska, Z. Zagórski, Poznań, s. 85-95.

Walczak B., 2015, Religijno-kościelny czynnik sprawczy rozwoju języka polskiego, w: Język tożsamości, seria: Język. Religia. Tożsamość, t. 9, red. G. Cyran, E. Skorupska-Raczyńska, Gorzów Wielkopolski, s. 185-200.

Witaszek-Samborska M., 1992, Wyrazy obcego pochodzenia we współczesnej polszczyźnie (na podstawie słowników frekwencyjnych), Poznań.

Witaszek-Samborska M., 1993, Zapożyczenia z różnych języków we współczesnej polszczyźnie (na podstawie słowników frekwencyjnych), Poznań. 